\title{
THERAPIES FOR CROHN'S DISEASE: a clinical update
}

\author{
Carlos Walter SOBRADO'1, Raquel Franco LEAL² and Lucas Faraco SOBRADO'1
}

Received 5/1/2016 Accepted 9/3/2016

\begin{abstract}
The main objectives of clinical therapy in Crohn's disease are clinical and endoscopic remission without the use of corticosteroids for long periods of time, prevention of hospitalization and surgery, and improvement of quality of life. The main limitation of drug therapy is the loss of response over the long term, which makes incorporation of new drugs to the therapeutic arsenal necessary. This review analyses the main drugs currently used in clinical treatment of Crohn's disease.
\end{abstract}

HEADINGS - Crohn disease, therapy. Immunosuppressive agents. Biologic therapy. Quality of life.

\section{INTRODUCTION}

The main goals in treating Crohn's disease (CD), taking into consideration the fact that this is a chronic disease that follows a course that includes periods of exacerbation and calmness, are: improvement of quality of life; preservation of bowel function; and use of drugs that can keep patients in clinical and endoscopic remission of the disease for extended periods without corticosteroids, while monitoring the possible adverse effects of medications.

All of the pharmacological treatment options available operate under the hypothesis that inflammatory bowel disease (IBD) is a condition resulting from hyperactivity of the immune system. The aim of this review is to discuss the main pharmacological classes for CD therapy and their indications based on the disease's severity, as determined mainly through endoscopic findings, and based on the previous medication history ${ }^{(9,28)}$.

\section{Aminosalicylates or salicylic derivatives}

The salicylic derivatives include sulfasalazine (SSZ) and mesalazine (MSZ). Through bacterial action, sulfasalazine splits into sulfapyridine and 5 - aminosalicylic acid (5-ASA or mesalazine). The 5-ASA fraction has topical anti-inflammatory action. The initial clinical approach towards mild cases, especially when there is colorectal involvement in the disease, is based on use of aminosalicylic derivatives (5-ASA). SSZ should be administered at a dose of 2 to $6 \mathrm{~g} /$ day and, every time it is used, folic acid ( 2 to 5 $\mathrm{mg} /$ day) needs to be prescribed because of the risk of macrocytic anemia, which is one of the complications associated with SSZ. Mesalamine is available for oral or topical use, and the recommended daily oral dose is from 2 to $4 \mathrm{~g} / \mathrm{day}^{(8,18,27,45,49,50)}$. 5-ASA derivatives are not recommended for inducing remission in active ileal $\mathrm{CD}$, given that a meta-analysis on 615 patients showed that these showed limited efficacy in comparison with placebo $^{(23)}$. It is important to emphasize that the efficacy of sulfasalazine for maintaining drug-induced remission has not been established and the efficacy of mesalazine for these situations remains a matter of controversy ${ }^{(2,11,29,46,48)}$. Therefore, 5-ASA is not recommended for maintaining remission of $\mathrm{CD}$ induced by other drugs such as corticosteroids. Mesalazine seems to provide a protective effect against the appearance of dysplasia and colorectal cancer in patients with colitis, and may be indicated in mild cases of $\mathrm{CD}$ with colonic involvement ${ }^{(12)}$.

\section{Antibiotics}

Antibiotics are primarily used in CD for acute exacerbations, toxic megacolon, abscesses, fistulas, sepsis and perineal involvement. CD patients present altered intestinal microbiota, which seems to be important in the pathogenesis of the chronic inflammatory process, and in some cases is responsible for acute $\operatorname{crises}^{(37)}$. The two classes of commonly used antibiotics are ciprofloxacin (1 g/day) and metronidazole (10-30 $\mathrm{mg} / \mathrm{kg}$ ) and their use can be extended for more than four weeks. Use of metronidazole in CD patients for three months after surgery is associated with reduced recurrence of severe endoscopic disease over a oneyear follow-up period after the surgical procedure, but there is no statistical difference in relation to placebo

Declared conflict of interest of all authors: Carlos Walter Sobrado has served as a consultant to Takeda, Farmoquímica. Disclosure of funding: no funding received

' Disciplina de Coloproctologia, Hospital das Clínicas da Faculdade de Medicina da Universidade de São Paulo (FMUSP), Brasil; ${ }^{2}$ Departamento de Cirurgia, Unidade de Coloproctologia, Universidade de Campinas (UNICAMP), Brasil.

Correspondence: Carlos Walter Sobrado. Instituto de Gastrocirurgia, Oncologia e Proctologia. Rua Itapeva, 500, $7^{\circ}$ andar. Bela Vista - CEP: $01332-000$ - São Paulo, SP, Brasil. 
in the subsequent second and third years ${ }^{(13,54)}$. Use of metronidazole should not extend for more than 16 weeks, because of its side effects, especially regarding peripheral neuropathy (upper and lower limbs), characterized by paresthesia, hypoesthesia and a burning sensation, which may be irreversible. There is no evidence for the use of antibiotics as maintenance therapy ${ }^{(10)}$.

\section{Corticosteroids}

Corticosteroids can be used in oral form (prednisone or prednisolone) or parenteral form (hydrocortisone) and are indicated in cases of moderate and severe active $\mathrm{CD}$. Prednisone at a dose of 0.75 to $1 \mathrm{mg} / \mathrm{kg} /$ day (maximum of $60 \mathrm{mg} /$ day) is indicated to induce clinical remission, which should occur within 2 to 4 weeks, after which phased withdrawal should begin. The purpose of its use is to reduce disease activity, but it does not change the natural evolution of the disease and it induces mucosal healing in only $29 \%$ of cases $^{(30)}$. Prednisone is a synthetic glucocorticoid of intermediate potency, and is converted in the liver into the active form of prednisolone. It is rapidly absorbed in most individuals, unless there is severe inflammation of the small intestine. The mechanism of action of corticosteroids relates to its ability to inhibit cell-mediated immunity and to its anti-inflammatory effect ${ }^{(49)}$. Patients who do not respond to corticosteroids or who are corticosteroid-dependent must undergo phased treatment, with introduction of immunosuppressants (azathioprine or 6-mercaptopurine) or biological therapy. This phased therapy is indicated in the following situations: clinical worsening within 6 weeks after withdrawal of steroids; need for more than two courses of corticosteroids over a one-year period; and symptom recurrence whenever the dose is reduced below $15 \mathrm{mg}$. Corticosteroids are not effective for maintenance therapy, and prolonged use is associated with significant adverse effects such as osteoporosis, osteonecrosis, peptic ulcer and posterior subcapsular cataract, among others ${ }^{(7,47)}$.

Budesonide in a dose of $9 \mathrm{mg} /$ day has been indicated in terminal ileum and ileocecal CD with mild to moderate activity. Budesonide is rapidly metabolized in its passage through the liver, less effective in controlling inflammatory activity than prednisolone, and has fewer adverse effects because the slightest change in plasma cortisol ${ }^{(33)}$. The budesonide was compared to prednisolone in nine randomized trials ${ }^{(44)}$. A Cochrane review concluded that prednisolone is more effective, especially in patients with pancolitis and with more severe inflammatory activity ${ }^{(44)}$. When comparing the results of oral budesonide ( $9 \mathrm{mg} /$ day) with 5 -ASA ( $4 \mathrm{~g} /$ day) in ileocecal CD patients after 16 weeks was observed a better clinical response in the corticosteroids group (budesonide $=69 \%$ and 5 -ASA $=45 \% ; P=0.001)^{(53)}$. Currently, oral budesonide $(9 \mathrm{mg} /$ day) is indicated to treat CD with mild to moderate activity, localized in the ileocecal region, however, it is inefficient as maintenance treatment (after 6 to 12 months) ${ }^{(19)}$.

\section{Immunosuppressants}

Azathioprine (AZA) and 6-mercaptopurine (6-MP) are potent immunosuppressants. They inhibit RNA synthesis and the activity of $\mathrm{T}$ and $\mathrm{B}$ lymphocytes and natural killer (NK) cells, and also induce T cell apoptosis. They are indicated for maintaining remission that has been achieved through use of corticosteroids and in association with biological therapy. Combination therapy (immunosuppressant + biological) presents better results, either through potentiation of immunosuppression, or through the diminished immunogenicity that is inherent to biological therapy. Considering the high risk of relapse that is characteristic of $\mathrm{CD}$, the dependence on corticosteroids and the high rate of response to immunosuppressant use when this is introduced early, azathioprine is the drug most indicated for maintaining remission that has been achieved through use of systemic corticosteroids ${ }^{(26,36)}$. AZA is metabolized in a non-enzymatic manner into mercaptopurine, which is subsequently metabolized to 6-thioguanine nucleotide (6-TGN), which is the active portion of the drug. The first choice is azathioprine (dose of 2 to $3 \mathrm{mg} / \mathrm{kg} / \mathrm{day}$ ), but 6-mercaptopurine (6-MP), followed by methotrexate, is also an option in cases of intolerance to azathioprine. 6-MP is used at a dose of 1 to $1.5 \mathrm{mg} / \mathrm{kg} / \mathrm{day}$. Methotrexate is a folate antagonist and interferes with DNA synthesis. It is indicated when there is intolerance to azathioprine or 6-MP, and the recommended starting dose is $25 \mathrm{mg}$ per week intramuscularly, decreasing to $15 \mathrm{mg} / \mathrm{week}$, three to four months after the onset of drug use ${ }^{(5,17)}$. Thus, immunosuppressants (AZA and 6-MP) are indicated in cases of resistance or refractory to corticosteroids, in the maintenance of remission achieved with corticosteroids and in the prevention of postoperative recurrence ${ }^{(12,16)}$. They are safe drugs that can be used during pregnancy $^{(12)}$. There are no studies comparing the efficacy of AZA and 6-MP in patients with CD, but some patients intolerant to azathioprine, can tolerate 6-MP. In addition, methotrexate is effective for maintenance of the remission and preventing clinical relapses, and its indication reserved for cases of intolerance or refractory to AZA and 6-MP(12,16).

The importance of this class of drugs mainly relates to maintenance of remission of $\mathrm{CD}$, since they are drugs with slow onset of action. This makes it necessary to wait at least 14 to 16 weeks for its full pharmacological effects. Therefore, other classes of drugs should be used to induce remission, such as corticosteroids or biological therapy, represented by inhibitors of tumor necrosis factor alpha (anti-TNF- $\alpha$ ). Adverse effects from immunosuppressants (AZA e 6-MP) may occur in up to $20 \%$ of the cases, most often in the first 2 to 3 weeks, and mainly comprise allergic reactions, leukopenia and hepatotoxicity ${ }^{(26,36)}$. The main adverse effects of methotrexate are hepatotoxicity, pneumonitis and gastrointestinal disorders (stomatitis, nausea, vomiting and diarrhea. The concomitant administration of folic acid (1-2mg/day orally) assists in preventing stomatitis, diarrhea and bone marrow toxicity ${ }^{(3)}$.

\section{Biological therapy}

Since the introduction of biological treatment for Crohn's disease in 1998, therapies directed towards tumor necrosis factor alpha have shown good efficacy as mediators of the inflammatory response. Biological therapy not only has successfully achieved the goals of traditional therapy (clinical response and remission), but also has made it possible 
to reach a new target: healing of the mucosa. Infliximab and adalimumab are anti-TNF- $\alpha$ monoclonal antibodies that have been approved for use in treating CD in Brazil. These drugs act through inhibiting the forms of TNF- $\alpha$ that are soluble in plasma, along with those that are linked to the transmembrane receptor, thereby inhibiting its proinflammatory actions. Infliximab was the first biological drug approved for CD; it is a chimeric antibody (75\% human) administered intravenously, whereas adalimumab is an entirely humanized antibody, administered subcutaneously. Indication of anti-TNF- $\alpha$ is based on cases of patients who fail to respond to conventional therapy (derived from aminosalicylates or immunosuppressants) and/or those who develop adverse effects to these therapies. It is in these situations especially that biological therapy is applied. It is indicated both for inducing remission during periods of exacerbation of the disease, and for maintaining clinical and endoscopic remission, with or without associated use of other drug classes $^{(14,20,22,24,34,35,38-40,43,51)}$. Initially, severe penetrating perianal disease was the main form of $\mathrm{CD}$ with an indication for biological therapy. Subsequently, its application was extended to luminal $\mathrm{CD}$ of the small intestine and colorectal $\mathrm{CD}^{(20,35)}$.

Concomitant use of immunosuppressants and infliximab was proposed in order to reduce the formation of autoantibodies against infliximab. Because infliximab consists of $25 \%$ murine antibodies, this confers greater immunogenicity to the drug and can cause adverse reactions or even decreased anti-inflammatory action. The SONIC study ${ }^{(15)}$ (Study of biological and immunosuppressive therapy in patients with $\mathrm{CD}$ without previous use of these treatments) revealed that combined therapy is more effective than exclusive use of infliximab to induce steroid-free remission and healing of the intestinal mucosa in patients who had not previously been treated with azathioprine. However, among patients who failed to respond to azathioprine, the benefit of combined therapy (infliximab + azathioprine) is less evident. Nonetheless, particularly because of the reduced immunogenicity, combined therapy is preferred in the majority of the clinical situations that require the use biological therapy.

The early introduction of anti-TNF combined or not with immunosuppressant (Top-down therapy) may be considered in selected cases. Patients with high risk of complications, as young patients with severe disease, stenotic and fistulizing disease, deep ulcerations and complex perianal disease are candidates for this approach ${ }^{(6)}$.

Important to emphasize that up to $40 \%$ of $\mathrm{CD}$ patients lose response to anti-TNF agents over the years. First of all, it is important to confirm endoscopic inflammatory activity in the intestinal mucosa, and exclude the presence of associated infectious diseases. The presence of insufficient serum level of the drug can be one of the causes for non-response. For this reason, optimize the dose is a strategy to regain response to the anti-TNF, as increase the dose (Infliximab - 10mg $/ \mathrm{kg}$ ) or decrease the interval between infusions (Infliximab every 4 weeks and Adalimumab $40 \mathrm{mg}$ weekly), before you consider replacing the biological ${ }^{(1)}$. The chance for another class of therapy is a stated strategy in cases of lack of response to therapy optimization and high levels of circulating antibodies against anti-TNF ${ }^{(1,25,32)}$. Although, there are no available testes for measure the drug level, neither the detection of antibodies anti-drugs in Brazil, the optimization has been done empirically.

There is no recommendations regarding the duration of treatment with immunosuppressive drugs and/or anti-TNF drugs, but when necessary, such drugs can be maintained for a long time, always evaluating the benefit and the risk of complications. However, in selected cases of patients with clinical and endoscopic remission for more than two years, the treatment may be discontinued after patient compliance ${ }^{(34)}$.

Monitoring of adverse effects and the possible complications arising from the use of immunosuppressants and biological therapy is extremely important, especially with the aim of avoiding opportunistic infections or even enabling early diagnosis and appropriate treatment. This includes outpatient screening prior to the beginning of treatment, comprising chest radiography, serological tests (hepatitis $\mathrm{B}$ and immunodeficiency virus), Mantoux-PPD test and updating of vaccinations, along with routine checkups over the course of the therapy and follow-up. Patients with active infection should not receive biological therapy, until the infectious process has been brought fully under control. If abscesses and fluid accumulations are present, these must first be drained and treated. Latent infections such as tuberculosis, hepatitis B or the immunodeficiency virus need to be excluded or treated before biological therapy is started. Attenuated live vaccines (chickenpox, oral polio, yellow fever and BCG) should be administered at least 3-4 weeks before the start of medication, or three months after drug discontinuation. All patients with IBD must be advised to undergo vaccination against influenza, pneumococci, HPV and hepatitis $\mathrm{B}^{(21)}$.

Another relevant topic to be addressed is the biosimilar, which is a copy of the original biological agent, which should be similar in physical structure and biological function. For approval, the biosimilar biological was initially tested in patients with rheumatoid arthritis and ankylosing spondylitis, and was subsequently approved for the inflammatory bowel diseases by comparability.

There are two biosimilar copy of the infliximab [InflectraHospira, Inc., Lake Forest, IL] and [Remsima- Celltrion Inc., South Korea] that have been authorized for the treatment of Crohn's disease and ulcerative colitis ulcerative, is already being used in clinical practice in some countries ${ }^{(4)}$.

So far, there are few studies in patients with $\mathrm{CD}$, and the results are conflicting ${ }^{(21)}$. This new topic in the biologics era remains to be better elucidated. Biosimilar results and safety for $\mathrm{CD}$ will be demonstrated as this drug begins to be used more widely in this specific group of patients ${ }^{(52)}$.

More recently, another class of biological drugs known as anti-integrin antibodies has been introduced into clinical practice. Vedolizumab (VDZ) is an inhibitor of $\alpha 4 \beta 7$ integrin and blocks migration of leukocytes into the intestinal endothelium. One of the mechanisms for perpetuating the inflammatory process in $\mathrm{CD}$ comprises increased vascular permeability. For there to be migration and recruitment 
of immune cells to the site where the inflammation began, adhesion molecules known as integrins need to be present on the surface of the circulating immune cells, and these molecules bind to endothelial receptors called addressins (ICAM = intracellular adhesion molecule; MAdCAM = mucosal addressing cellular adhesion molecule). Agents that have been developed to block these molecules cause migration of immune cells through the endothelium, so as to decrease the inflammation. Thus, VDZ binds to $\alpha 4 \beta 7$ integrin, thereby preventing it from binding to the endothelial addressins (MAdCAM-1) and selectively preventing adhesion and subsequent migration of leukocytes into the intestine. Because VDZ has selective action in the intestine, it has fewer adverse effects than natalizumab (anti-integrin $\alpha 4 \beta 1$ ). Because it does not affect the passage of leukocytes to the central nervous system, it theoretically does not present any risk of progressive multifocal leukoencephalopathy. VDZ is a humanized IgG4 antibody that is administered intravenously every eight weeks. In a phase III randomized double-blind placebo-controlled study (GEMINI II) that included protocols both for induction of remission and for maintenance, $50 \%$ of the patients had already been exposed to anti-TNF- $\alpha$ therapy. The clinical remission rate after 52 weeks was $39 \%$ for VDZ (every 8 weeks), 36.4\% for the VDZ group (every 4 weeks) and $21.6 \%$ for the placebo $(P<0.001$ and $P=0.004)$. The remission rate without use of corticosteroids was $31.7 \%$ (VDZ every 8 weeks), $28.8 \%$ (VDZ every 4 weeks) and $15.9 \%$ (placebo) $(P=0.02$ and $P=0.04)$. The response rates were $43.5 \%, 45.5 \%$ and $30.1 \%$ respectively $(P=0.01$ and $P=0.005)$ ${ }^{(41)}$. The GEMINI III study evaluated the response relating to induction in 315 patients with moderate/severe $\mathrm{CD}$ who had previously been exposed to one or more anti-TNF- $\alpha$ agents and had not shown any response, had had loss of response or were intolerant. Two intravenous infusions of VDZ (300 $\mathrm{mg}$ ) were applied in weeks 0 and 2 , and the response rate after 6 weeks was $39.2 \%$ (VDZ) and $22.3 \%$ (placebo) $(P=0.001)$. The clinical remission rate after 6 weeks was $15.2 \%$ (VDZ) and $12.1 \%$ (placebo) $(P=0.43)$. After an additional infusion in the sixth week, the remission rate at 10 weeks was $26.6 \%$ (VDZ) and $12.1 \%$ (placebo) $(P=0.001)^{(42)}$. The infection rates and safety analyses were encouraging, with serious infections observed in $5.5 \%$ (VDZ) and $3 \%$ (placebo $)^{(41)}$. The VDZ to be selective action in the intestine, does not seem to predispose enteric infection (Ex: Clostridium difficile) such as anti TNF therapy ${ }^{(31)}$. Subanalysis studies on GEMINI II subdivided the patients according to age, into three groups $(<35$ years, 35 years to 55 years and $>55$ years), and this revealed that VDZ may also have an important role among patients over the age of 55 years, because at week 52 (maintenance), $41 \%$ of the patients over 55 years of age remained in clinical remission without any increase in adverse effects ${ }^{(55)}$. Thus, biological therapies constitute a major advance in treating luminal and fistulizing CD. Anti-TNF- $\alpha$ therapies induce clinical remission very quickly, but on the other hand, antiintegrin molecules exhibit slower onset of action and, in some cases, they may require "bridge" therapy such as use of corticosteroids until they reaches their full action. (Table 1).
TABLE 1. Main drugs in clinical practice, recommended doses and administration routes

\begin{tabular}{|c|c|c|}
\hline Drug & Recommended dose & $\begin{array}{c}\text { Observations / } \\
\text { Guidance }\end{array}$ \\
\hline Sulfasalazine & $\begin{array}{l}2 \text { to } 6 \mathrm{~g} / \mathrm{day} \\
\text { Oral route }\end{array}$ & $\begin{array}{c}\text { Mild CD } \\
\text { Colorectal involvement }\end{array}$ \\
\hline Mesalazine & $\begin{array}{c}2 \text { to } 4 \mathrm{~g} / \mathrm{day} \\
1.6 \text { to } 3.2 \mathrm{~g} / \mathrm{day} \\
\text { Oral route }\end{array}$ & $\begin{array}{c}\text { Mild CD } \\
\text { Colorectal involvement }\end{array}$ \\
\hline $\begin{array}{l}\text { Corticosteroids } \\
\text { (prednisone) }\end{array}$ & $\begin{array}{c}0.75 \text { to } 1 \mathrm{mg} / \mathrm{kg} / \mathrm{day}, \mathrm{up} \text { to } \\
60 \mathrm{mg} / \mathrm{day} \text { (maximum) } \\
\text { Oral route }\end{array}$ & $\begin{array}{c}\text { Active } \mathrm{CD} \text {, only } \\
\text { induction of remission }\end{array}$ \\
\hline Budesonide & $\begin{array}{l}9 \mathrm{mg} / \mathrm{day} \\
\text { Oral route }\end{array}$ & $\begin{array}{l}\text { Mild to moderate CD } \\
\text { Terminal ileum / } \\
\text { ileocecal involvement }\end{array}$ \\
\hline Azathioprine & $\begin{array}{l}2 \text { to } 3 \mathrm{mg} / \mathrm{kg} / \mathrm{day} \\
\text { Oral route }\end{array}$ & $\begin{array}{l}\text { Maintenance of } \\
\text { remission } \\
\text { Slow onset of action }\end{array}$ \\
\hline 6-Mercaptopurin & $\begin{array}{c}1 \text { to } 1.5 \mathrm{mg} / \mathrm{kg} / \mathrm{day} \\
\text { Oral route }\end{array}$ & $\begin{array}{l}\text { Maintenance of } \\
\text { remission } \\
\text { Slow onset of action }\end{array}$ \\
\hline Methotrexate & $\begin{array}{l}25 \mathrm{mg} / \text { Week } \\
\text { Intramuscular route }\end{array}$ & $\begin{array}{c}\text { Maintenance of } \\
\text { remission } \\
\text { Indicated for patients } \\
\text { with intolerance to AZA } \\
\text { and 6-MP }\end{array}$ \\
\hline Infliximab & $\begin{array}{c}5 \mathrm{mg} / \mathrm{kg} \text { in weeks } 0,2 \text { and } \\
6 \text { (attack) and maintenance } \\
\text { every } 8 \text { weeks. } \\
\text { Intravenous route }\end{array}$ & $\begin{array}{l}\text { Increase to } 10 \mathrm{mg} / \mathrm{kg} \text { or } \\
\text { reduce the time between } \\
\text { each infusion to every } \\
4-6 \text { weeks, if there is } \\
\text { loss of response }\end{array}$ \\
\hline Adalimumab & $\begin{array}{l}160 \mathrm{mg} \text { and } 80 \mathrm{mg} \text { with } \\
\text { a } 2 \text {-week interval (attack) } \\
\text { and maintenance with } \\
40 \mathrm{mg} \text { every } 2 \text { weeks. } \\
\text { Subcutaneous route }\end{array}$ & $\begin{array}{c}\text { Reduce the time } \\
\text { between each infusion } \\
\text { to weekly if there is loss } \\
\text { of response }\end{array}$ \\
\hline Vedolizumab & $\begin{array}{l}300 \mathrm{mg} \text { IV in weeks } 0,2 \\
\text { and } 6 \text { (attack) and } \\
300 \mathrm{mg} \text { IV every } 8 \text { weeks } \\
\text { (maintenance). } \\
\text { Intravenous route }\end{array}$ & $\begin{array}{c}\text { Onset of action may } \\
\text { be slow }\end{array}$ \\
\hline
\end{tabular}

\section{CONCLUSION}

Decisions for the management of CD therapy must be based on objective tests as endoscopic examination, radiologic exams as magnetic resonance imaging (MRI), associated with others biomarkers as calprotectin and C-reactive protein (CRP). The assessment of the intestinal mucosa status is still the best tool for monitoring these patients and the response to the therapy, once clinical manifestations not always correlate well with the endoscopic or radiologic findings. In the present review, the main classes of drugs for treating $\mathrm{CD}$ were addressed. 
Immunosuppressants and biological agents are the most relevant class of drugs for this purpose. Despite the initial benefit of anti-TNF- $\alpha$, a significant number of patients, about $30 \%$, lose response over time. In the long-term outcome, $40 \%$ show no sustained benefit with this therapy. The main causes for lack of response include: insufficient dose (low serum drug levels) and the development of antibodies against the drug. For this reason, dose escalation, i.e. increasing the dose in non-responders with insufficient drug level, is an important clinical strategy to regain response to the drug and achieve mucosal healing. In those cases high titles of antibodies against the drug, that do not respond to the increase of the dose, switch the class of biological agent is the best option.
Because of the genetic and phenotypic heterogeneity of $\mathrm{CD}$, it is certain that no medication can be used to treat all patients because the same results will not be obtained in all cases. Incorporation of new classes of drugs for treating CD is important and necessary for increasing the therapeutic arsenal, and for performing targeted therapy, since it is known that a significant proportion of the patients do not respond to the drugs available.

\section{Authors' contribuitions}

Sobrado CW: Acquisition of data, interpretation of data; drafting and writing of the manuscript. Leal RF: critical revision of the manuscript for important intellectual content. Sobrado LF: Search literature and data collection.

Sobrado CW, Leal RF, Sobrado LF. Terapia farmacológica em portadores de doença de Crohn. Atualização clínica. Arq Gastroenterol. 2016,53(3):206-11. RESUMO - Os principais objetivos da terapia clínica na doença de Crohn são a remissão clínica e endoscópica por tempo prolongado, sem o uso de corticosteroides, além de evitar hospitalizações e cirurgias, e melhorar a qualidade de vida. A principal limitação da terapêutica medicamentosa é a perda de reposta a longo prazo, o que faz com que a incorporação de novas drogas ao arsenal terapêutico seja necessária. Esta revisão aborda os principais medicamentos utilizados atualmente no tratamento clínico da doença de Crohn.

DESCRITORES - Doença de Crohn, terapia. Imunossupressores. Terapia biológica. Qualidade de vida. 


\section{REFERENCES}

1. Afif W, Loftus EV Jr, Faubion WA, Kane SV, Bruining DH, Hanson KA, Sandborn WJ. Clinical utility of measuring infliximab and human anti-chimeric antibody concentrations in patients with inflammatory bowel disease. Am J Gastroenterol. 2010;105:1133-9.

2. Akobeng AK, Thomas AG. Enteral nutrition for maintenance of remission in Crohn's disease. Cochrane Database Syst Rev. 2007;3:CD005984.

3. Alfadhli AA, McDonald JW, Feagan BG. Methotrexate for induction of remission in refractory Crohn's disease (Cochrane Review). Cochrane database Syst Rev. 2003:CD003459.

4. Annese V, Vecchi M. Use of biosimilars in inflammatory bowel disease: Statements of the Italian Group for inflammatory Bowel Disease. Digestive and Liver Dis. 2014;46:963-8.

5. Arora S, Katkov W, Cooley J, et al. Methotrexate in Crohn's disease: results of a randomized, double-blind, placebo controlled trial. Hepatogastroenterology. 1999;46:1724-9.

6. Beaugerie L, Seksik P, Nion-Larmurie I, et al. Predictors of Crohn's disease. Gastroenterology. 2006;130:650-6.

7. Benchimol EI, Seow CH, Otley AR, Steinhart AH. Budesonide for maintenance of remission in Crohn's disease. Cochrane Database Syst Rev. 2009;1:CD002913.

8. Bernstein CN, Fried M, Krabshuis JH, et al. World Gastroenterology Organization Practice Guidelines for the daygnosis and management of IBD in 2010. Inflamm Bowel Dis. 2010;16:112-24.

9. Best WR, Becktel JM, Singleton JW, et al. Development of a Crohn's disease activity index. National Cooperative Crohn's disease Study. Gastroenterology. 1976;70:439-44.

10. Borgaonkar M, MacIntosh D, Fardy J, Simms L. Anti-tuberculous therapy for maintaining remission of Crohn's disease. Cochrane Database Syst Rev. 2000;2:CD000299.

11. Camma C, Giunta M, Rosselli M, Cottone M. Mesalamine in the maintenance treatment of Crohn's disease: a meta-analysis adjusted for confounding variables. Gastroenterology. 1997;113:1465-73

12. Carter MJ, Lobo SP, Travis SPL. Guidelines for the management of inflammatory bowel disease in adults. Gut. 2004;53(Suppl V):V1-V16.

13. Colombel JF, Lemann M, Cassagnou M, et al. Groupe d'Etudes Therapeutiques des Affections Inflammatoires Digestives (GETAID). A controlled trial comparing ciprofloxacin with mesalazine for the treatment of active Crohn's disease. Am J Gastroenterol. 1999;94:674-8.

14. Colombel JF, Sandborn WJ, Rutgeerts P, Enns R, Hanauer SB, Panaccione R, et al. Adalimumab for maintenance of clinical response and remission in patients with Crohn's disease: the CHARM trial. Gastroenterology. 2007;132:52-65.

15. Colombel JF, Sandborn WJ, Reinisch W, Mantzaris GJ, Kornbluth A, Rachmilewitz D, Lichtiger S, D’Haens G, Daymond RH, Broussard DL, Tang KL, van der Woude CJ, Rutgeerts P, et al. Infliximab, azathioprine, or combination therapy for Crohn's disease. N Engl J Med. 2010;362:1383-95.

16. Dignass A, Van Assche G, Lindsay M, et al. The second European evidence-based consensus on the diagnosis and management of Crohn's disease: Current management. J Crohn's Colitis. 2010;4:28-62.

17. Feagan BG, Fedorak RN, Irvine EJ, et al. A comparison of methotrexate with placebo for the maintenance of remission in Crohn's disease. North American Crohn's Study Group Investigators. N Engl J Med. 2000;342:1627-32.

18. Feagan BG. Editorial: 5-ASA therapy for active Crohn's disease: old friends, old data and a new conclusion. Clin Gastroenterol Hepatol. 2004;2:376-8.

19. Ferguson A, Campieri M, Doe W, et al. Oral budesonide as maintenance therapy in Crohn's disease-results of a 12-month study. Global Budesonide Study Group. Aliment Pharmacol Ther. 1998;12:175-83.

20. Fidder HH, Hommes DW. Anti-TNF and Crohn's disease: when should we start? Current Drug Targets. 2010,11:143-7.

21. Flores C. Imunizações na doença inflamatória intestinal. In Doença Inflamatória Intestinal. Editores Cardozo WS \& Sobrado CW. $2^{\circ}$ ed, São Paulo, Manole; 2015. p.601-14.

22. Hanauer SB, Feagan BG, Lichtenstein GR, et al. Maintenance infliximab for Crohn's disease: the ACCENT 1 randomised trial. Lancet. 2002;359:1541-9.

23. Hanauer SB, Stromberg V. Oral pentasa in the treatment of active Crohn's disease: a meta-analysis of double-blind, placebo-controlled trials. Clin Gastroenterol Hepatol. 2004;2:379-88.

24. Hanauer SB, Sandborn WJ, Rutgeerts P, Fedorak RN, Lukas M, MacIntosh D, et al Human anti-tumor necrosis factor monoclonal antibody (adalimumab) in Crohn's disease: the CLASSIC-I trial. Gastroenterology. 2006;130:323-33.

25. Leal RF, Planell N, Kajekar R, Lozano JJ, Ordás I, Dotti I, Esteller M, Masamun MC, Parmar H, Ricart E, Panés J. Identification of inflammatory mediators in patients with Crohn's disease unresponsive to anti-TNFá therapy. Gut. 2015;64:233-42.

26. Lémann M, Mary JY, Colombel J-F, et al. A randomized, doubleblind, controlled withdrawal trial in Crohn's disease patients in long-term remission on azathioprine. Gastroenterology. 2005;128:1812-8.
27. Malchow H, Ewe K, Brandes JW, et al. European co-operative Crohn's disease study (ECCDS): results of drug treatment. Gastroenterology. 1984;86:249-66.

28. Mary JY, Modigliani R. Development and validation of an endoscopic index of the severity for Crohn's disease: a prospective multicentre study. Groupe d'Etudes Therapeutiques des Affections Inflammatoires du Tube Digestif (GETAID). Gut. 1989;30:983-9.

29. Messori A, Brignola C, Trallori G, Rampazzo R, Bardazzi G, Belloli C, et al. Effectiveness of 5-aminosalicylic acid for maintaining remission in patients with Crohn's disease: a meta-analysis. Am J Gastroenterol. 1994;89:692-8.

30. Modigliani R, Mary J, Simon J. Clinical, biological and endoscopy picture of attacks of Crohn's disease. Evolution on prednisolone. Gastroenterology. 1990;98:811-8.

31. O'Regan K, et al. Gastroenterology. 2015;148:S-235. Abstract Sa 1132.

32. Ordás I, Feagan BG, Sandborn WJ.Therapeutic drug monitoring of tumor necrosis factor antagonists in inflammatory bowel disease. Clin Gastroenterol Hepatol. 2012;10:1079-87.

33. Otley A, Steinhart AH. Budesonide for induction of remission in Crohn's disease. Cochrane Database Syst Rev. 2005:CD000296. Review.

34. Oussalah A, Danese S, Peyrin-Biroulet L. Efficacy of TNF antagonists beyond one year in adult and pedaytric inflammatory bowel diseases: a systematic review. Current Drug Targets. 2010;11:156-75.

35. Panés J, Gomollón F, Taxonera C, et al. Crohn's disease. A review of current treatment with a focus on biologics. Drugs. 2007;67:2511-37.

36. Pearson DC, May GR, Fick GR, Sutherland LR. Azathioprine for maintaining remission of Crohn's disease. Cochrane Database Syst Rev. 2000:CD000067.

37. Podolsky DK. Inflammatory bowel disease. N Engl J Med. 2002;347:417-29.

38. Rutgeerts P, D’Haens G, Van Assche G, et al. Adalimumab induces and maintains mucosal healing in patients with moderate to severe Crohn's disease. First results of the EXTEND trial. Gastroenterology. 2009;136:A116. Abstract.

39. Sandborn WJ, Hanauer SB, Rutgeerts P, et al. Adalimumab for maintenance treatment of Crohn's disease: results of the CLASSIC II trial. Gut. 2007;56:1232-9.

40. Sandborn WJ, Rutgeerts P, Enns R, Hanauer SB, Colombel JF, Panaccione R, et al Adalimumab induction therapy for Crohn disease previously treated with infliximab: a randomized trial. Ann Intern Med. 2007;146:829-38.

41. Sandborn WJ, Feagan BG, Rutgeerts P, et al. Vedolizumab as induction and maintenance therapy for Crohn's disease. N Eng J Med. 2013;369:711-21.

42. Sands BE, Feagan BG, Rutgeerts P, et al. Effects of vedolizumab induction therapy for patients with Crohn's disease in whom tumor necrosis fator antagonista treatment failed. Gastroenterology. 2014;147:618-27.

43. Schnitzler F, Fidder H, Ferrante M, Noman M, Arijs I, Van Assche G, et al. Longterm outcome of treatment with infliximab in 614 patients with Crohn's disease: results from a single-centre cohort. Gut. 2009;58:492-500.

44. Seow CH, Benchimol EI, Griffiths AM, et al. Budesonide for induction of remission of Crohn's disease. Cochrane Database Syt Rev. 2008; 1:CD00296.

45. Singleton JW, Hanauer SB, Gitnick GL, et al. Mesalamine capsules for the treatment of active Crohn's disease: results of a 16-week trial. Gastroenterology. 1993; 104:1293-301

46. Steinhart AH, Hemphill D, Greenberg GR. Sulfasalazine and mesalazine for the maintenance therapy of Crohn's disease: a meta-analysis. Am J Gastroenterol 1994;89:2116-24

47. Steinhart AH, Ewe K, Griffiths AM, Modigliani R, Thomsen OO. Corticosteroids for maintaining remission of Crohn's disease. Cochrane Database Syst Rev. 2003:CD000301

48. Steinhart AH, Forbes A, Mills EC, et al. Systematic review: the potential influence of mesalazine formulation on maintenance of remission in Crohn's disease. Aliment Pharmacol Ther. 2007;25:1389-99.

49. Summers RW, Switz DM, Sessions JT, et al. National cooperative Crohn's disease study group: results of drug treatment. Gastroenterology. 1979;77:847-69.

50. Sutherland LR, Martin F, Bailey RJ, et al. A randomized, placebo-controlled, double-blind trial of mesalamine in the maintenance of remission of Crohn's disease. The Canadayn Mesalamine for Remission of Crohn's Disease Study Group. Gastroenterology. 1997;112:1069-77.

51. Targan SR, Hanauer SB, van Deventer SJ, et al. A short-term study of chimeric monoclonal antibody cA2 to tumor necrosis factor alpha for Crohn's disease. Crohn's Disease cA2 Study Group. N Engl J Med. 1997;337:1029-35.

52. Teixeira FV, Kotze PG, Damião, et al. Biosimilars in inflammatory bowel Diseases: an importante moment for Brazilians gastroenterologists. Arq Gastroenterol. 2015;52:76-80.

53. Thomsen $\mathrm{O}$, Cortot $\mathrm{A}$, Jewell $\mathrm{D}$, et al. A comparision of budesonide and mesalamine for active Crohn's disease. N Engl J Med. 1998;339:370-4.

54. Ursing B, Alm T, Barany F, et al. A comparative study of metronidazole and sulfasalazine for active Crohn's disease: the cooperative Crohn's disease study in Sweden. Gastroenterology. 1982;83:550-62.

55. Yajnik V, et al. J Crohn's Colitis. 2015,9(Supp 1):S244-S245. Abstract P330. 